\title{
Nuclear stockpile controls under fire in US
}

Washington. The largest programme at the US nuclear weapons laboratories is a "smokescreen" that will not achieve its stated goals of ensuring the safety and reliability of the nuclear weapons stockpile, according to a report published last week by a watchdog group based in Washington DC.

The report, The Nuclear Safety Smokescreen, has been produced by the Institute for Energy and Environmental Research

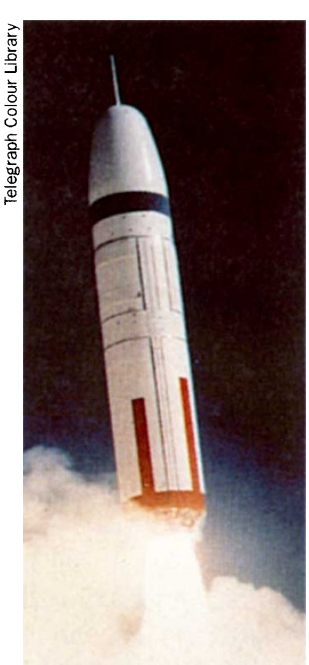

(IEER). It uses new data on recorded safety and reliability problems to attack the basis for the Department of Energy (DOE)'s Science-base Stockpile Stewardship programme.

Since the United States stopped testing nuclear weapons in 1992 , the $\$ 1.5$ billion stewardship programme has become the mainstay of the three nuclear weapons laboratories - Los Alamos One less to stockpile: and Sandia in Trident on test. New Mexico, and Lawrence Livermore in California. The DOE spends a further $\$ 1.5$ billion a year on "stockpile management", which covers the everyday management of the weapons.

The programme concentrates the energies of former weapons designers on establishing how the safety and reliability of the existing weapons will change with age. It includes two major new scientific facilities - the planned National Ignition Facility at Livermore and the Dual Axis Radiographic Hydrodynamic Test Facility (DARHT) under construction at Los Alamos - which IEER says should be cancelled.

The IEER, a technically competent but fiercely anti-nuclear nonprofit group, claims that the DOE has grouped "safety and reliability" together in order to justify the programme. But the technical issues of safety (against accidental detonation) and reliability in service are independent of each other, the report says.

Stockpile stewardship will not be concerned with the safety issues at all, it adds, while the reliability issues it does address will matter only if the United States intends to use its stockpile in a massive 'first strike' against an enemy power.

The DOE defends the stockpile stewardship programme which, it says, will provide the United States with information on safety and reliability which it would once have got through testing, in order to decide how the stockpile should be managed.
"Science-based stockpile stewardship will give scientists and engineers the tools to make these judgements," says Stephen Guidice, a senior DOE official who is now drawing up the environmental impact statement that is intended to provide a public justification for the programme.

Historical data released to the IEER by the department show that none of the 37 safety problems identified in the nuclear primary component of weapons had been attributed to ageing. About a quarter of the reliability problems were attributed to ageing - but 70 per cent of them reduced reliability by one per cent or less.

But Guidice says that the historical information does not provide an accurate guide to the future, as the stockpile was always replenished and only a few years old. Its average age is now 13 years - the oldest it has ever been. "We are now going into an area on which we have very little data," he says. Designers know that the nuclear warheads will change with age as a result of both corrosion and radioactive decay, Guidice says.

James Mercer-Smith, deputy director of nuclear weapons technology at Los Alamos, adds: "As the stockpile ages far beyond its anticipated life, we can expect a variety of defects which will break the symmetries which were used in the design process".

Arjun Makhijani, president of IEER, says that even if ageing is an issue, the stockpile stewardship programme is not the way to deal with it. Existing monitoring procedures, which withdraw and inspect eleven warheads of each type every year and cut up the nuclear part of one of them to check for defects and remanufacture defective parts as needed, would suffice, he thinks.

Frank von Hippel, professor of Public and International Affairs at Princeton University and a former senior official in the Clinton administration, wrote last year in the Journal of the Federation of American Scientists that the programme was a "very costly" concession to the weapons laboratories, offered to secure their support for an end to testing.

But the programme has robust support in the Congress, where many members recognize that its true goal is not the maintenance of the stockpile but the maintenance of the skills of the three weapons laboratories.

Colin Macilwain

\section{Public faith in science stays high}

Washington. The American public continues to hold science in respect, with threequarters of the population believing that the benefits of research outweigh its harmful results, and little evidence of a strong 'antiscience' mood, according to data gathered by the National Science Foundation.

The percentage has held more or less constant since the data were first collected in 1979, and is reported in Science and Engineering Indicators 1996, the NSF's massive biennial report on the statistical status of US science, which was published in Washington last week.

Jon Miller, vice-president of the Chicago Academy of Sciences, and main author of the report's section on the public understanding of science, says that there is no trace of the much-touted anti-science movement in the findings. "We couldn't find it before, and we can't find it now — and we've looked very hard for it," he says.

But the public's support for science is not matched by an understanding of how it works, Miller says. Although half the sample, for example, agreed that a clinical trial should put 500 subjects on a drug and keep 500 off it - rather than putting 1,000 people on the drug straight away — almost half of them thought the reason for keeping the 500 on placebo was to save them from the risk of being poisoned.

The report confirms that total spending on research in the United States has been in steady decline during the 1990s. Industry's investment in research and development (R\&D) has held steady at around \$79 billion (in 1987 dollars), but the real value of the government's contribution has fallen 20

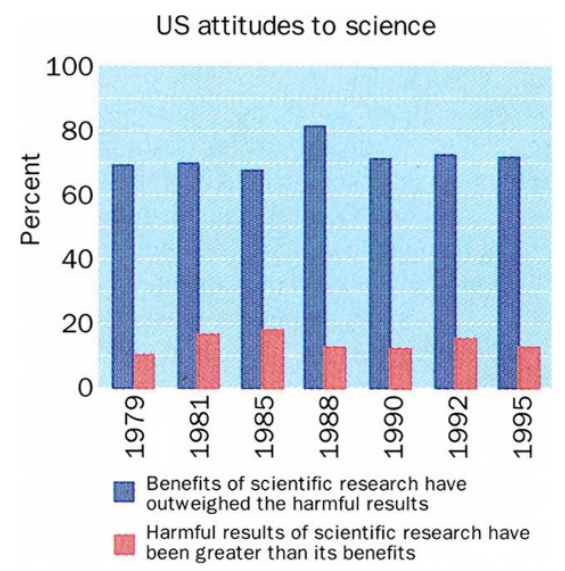

per cent since its 1987 peak.

As a percentage of the US economy, this means that US R\&D has collapsed from 2.8 per cent of gross domestic product (GDP) in 1991 to 2.4 per cent last year. Much of that decline has been attributable to defence cutbacks, but non-defence R\&D has also fallen, from 2.17 per cent in 1991 to 1.94 per cent last year. In an August 1994 policy document, the Clinton administration said that its long-term goal was to raise this last figure to 3 per cent of GDP.

C. M. 